\title{
ANTI-BIOFILM ACTIVITY OF FERMENTED SOYBEAN TEMPEH EXTRACTS AND FRACTIONS AGAINST ORAL PRIMARY COLONIZER BACTERIA
}

\author{
Allimalar Sathiaseelan ${ }^{1}$, Chong Seng Shit ${ }^{2}$, Tsun-Thai Chai ${ }^{3}$ \\ ${ }^{I}$ Department of Biological Science, Faculty of Science, Universiti Tunku Abdul Rahman \\ 31900 Kampar, Perak, Malaysia. \\ ${ }^{2}$ Centre for Bio-diversity Research, Universiti Tunku Abdul Rahman, \\ 31900 Kampar, Perak, Malaysia \\ ${ }^{3}$ Department of Chemical Science, Faculty of Science, Universiti Tunku Abdul Rahman \\ 31900 Kampar, Perak, Malaysia.
}

\begin{abstract}
In early dental plaque formation, oral primary colonizers, Actinomyces viscosus is initially attached to the pellicle-coated tooth surface to form a biofilm. Tempeh is a Southeast Asian traditional food produced from fermented soybean. This study, for the first time, investigated the in vitro inhibitory effects of tempeh extracts and fractions in removing oral primary biofilm on a polystyrene 96-well microtiter plate. Initial cell attachment was evaluated in this study after treatment with tempeh extracts and fractions at various concentrations ( 0 to $3 \mathrm{mg} / \mathrm{mL}$ ). The growth and development of the biofilm was assessed using the crystal violet assay. Anti-biofilm activity of tempeh extract and fractions were measured as the percentage of the biofilm inhibition after the treatment in comparison with the untreated control. Following fractionation of chloroform extract, the resulting hexane fraction was found to be active against $A$.viscosus. Data from colorimetric assay were confirmed by scanning electron microscopy (SEM) analysis. SEM analysis revealed significant reduction in biomass, as well as decrease of total cell volume and thickness when intact $A$.viscosus biofilms were treated with chloroform extract and hexane fraction. These results suggest that soybean tempeh is a promising source of bioactive compounds that can be used as natural ingredients for future development of oral care products targeting biofilm formation.
\end{abstract}

Keywords: Actinomyces viscosus, anti-biofilm activity, tempeh, fermented soybean, oral bacteria

\section{Introduction}

Dental plaque biofilms exist via the attachment, detachment and proliferation of oral bacteria on the tooth surface. This is primarily associated with adhesion of bacteria to pellicle coating the oral surface (Steinberg D. 2000). Biofilms are well known as an initiator for primary dental diseases (Takahashi N. et al., 2011) by safeguarding the bacteria against the action of antibiotics and antimicrobial agents through the matrix barrier (Costerton W. et al., 2003). Taking into account that adherence is essential for colony formation; preventing bacterial adhesion would appear to be a logical approach for reducing biofilm formation (Kostakioti et al., 2013). If this adhesion could be disrupted by food products, the bacteria would not be able to colonize nor cause infection (Nataro and Kaper, 1998; Nagy and Fekete, 2005). The efficient tooth colonizer, A. viscosus is a Gram positive bacterium primarily adhering to dental surface contributing to oral biofilm development at initial stages (Socransky et al. 1977; Theilade et al. 1982; Nyvad and Kilian 1987; Gibbons 1989; Marsh and Martin 1992). Therefore, the reduction of initial A. viscosus biofilm development is an effective way to prevent plaque related periodontal diseases. 
Forasmuch as, biofilm forming bacteria are more resistant to antimicrobial agents (Stewart and Costerton, 2001), developing new strategies to control this variegated mode of bacterial life is greatly challenging (Trentin et al., 2013). In recent years, plant products which may be bioactive against cariogenic and periodontopathogen have been of great interest to the researchers in the field of oral biofilm control, mainly due to their few after-effects. Plant phenolic compounds which already revealed their antimicrobial and anti-biofilm activities (Slobodníková, Lívia et al., 2016) have brought hope.

It has become a hot spot for researchers to delve into traditional fermented food products that can control biofilm formation. A shift of interest has been recently experienced with anti-biofilm activity from fermented foods of plant origin such as red wine against oral Streptococcus mutans biofilm (Maria Daglia et al., 2010), Lactobacilli extracts from traditional Tunisian fermented food against Listeria monocytogenes biofilm (Ben Slama et al., 2013), Lactobacillus strains isolated from Sorghum-based traditional fermented food active against Pseudomonas aeruginosa and Klebsiella pneumonia biofilm (Rao et al., 2015), lactic acid bacteria isolated from barley, traditional dried meat and fermented olive were characterized for their anti-biofilm activities against oral bacteria (Fadia Ben Taheur et al., 2016), Kimchi - a traditional Korean fermented food showed potential for invasion protection against Pseudomonas aeruginosa (Khan and Kang, 2016) and loads more.

With this background, we began anti-biofilm studies of tempeh, fermented food from soybeans by fungus, Rhizopus oligosporus. Tempeh is an emblematic traditional food from Indonesia and is a commonly available in Malaysia. During fermentation, the soybeans are bound together by the mycelium of the mould into a compact cake and macronutrients are enzymatically degraded. Interest in the potential of soybeans as an attractive functional food product has been on the rise for daily consumption due to its increased nutritive value during fermentation (Murata $\mathrm{K}$ et al., 1967).

In regard to tempeh, it has already been documented to exert various microbial activities (Murakami et al., 1984; Sutardi and Buckle 1985; Keuth and Bisping, 1993; Kiers et al., 2002; Tsangalis et al., 2002; Roubos et al., 2008; Haron et al., 2010; Haron et al., 2011). Tempe also has been shown to inhibit ETEC infection in rabbits (Karyadi et al., 1990; Karmini et al., 1997). Kiers et al. (2002) focused on ETEC adhesion to piglet brush border cells, as affected by tempeh. Moreover, Roubos van den Hill et al. (2009) confirmed the interference of tempeh toward Enterotoxigenic Escherichia coli adhesion for intestinal epithelial cells to intestinal epithelial cells of pig and human origin, Caco-2 cells. A study by Mo et al. (2011) comparing the anti-adhesive activity of tempeh and tofu from soybean origins disclosed that both have an anti-adhesive activity against Escherichia coli in vitro. In addition to it, recent study by Kuligowski M. et al. (2013) has successfully evaluated the antibacterial properties of soybean tempeh that has influence on human intestine bacteria with the use of an in vitro digestion model. This result strengthened previous observation of the anti-adhesion properties of soybean tempeh.

It is noteworthy that the crude tempeh does exert its anti-adhesion effect against wide range bacteria species. This study was therefore undertaken to investigate for the first time the in vitro anti-biofilm potential of tempeh against $A$. viscosus biofilms with the use of microtiter model. 


\section{Materials and Methods}

\section{Preparation of tempeh sample}

Commercial tempeh samples were purchased from a cottage industry producer in Sepang, Selangor DE, Malaysia. The tempeh blocks were lyophilised to obtain a constant mass and the percentage of water and solid content were calculated. Then, the tempeh was ground to a fine powder using a mechanical blender. The dry weight was determined, and the powder was stored in an air-tight container at $-20{ }^{\circ} \mathrm{C}$ until further use.

\section{Bacterial strains and culture conditions}

The oral microorganism used in this study is Actinomyces viscosus (ATCC 43146). This strain was cultured in brain heart infusion (BHI; Merck, Germany) broth under anaerobic condition in a packrectangular anaerobic jar (Mitsubishi Gas Chemical Co.Inc, Japan), $37{ }^{\circ} \mathrm{C}$ for $16-24 \mathrm{~h}$ and subculturing was done twice weekly. For growth curve analysis, A. viscosus were grown as described above, was diluted in BHI to obtain a final bacterial optical density measurement at $600 \mathrm{~nm}\left(\mathrm{OD}_{600 \mathrm{~nm}}\right)$ of 0.1 McFarland Standard. The cultures were then incubated at $37^{\circ} \mathrm{C}$ overnight.

\section{Sequential solvent extraction and fractionation}

The tempeh powder was sequentially extracted with a series of solvents differing in polarity. First, it was extracted using hexane (1: $10 \mathrm{w} / \mathrm{v})$ at room temperature using incubator shaker at the speed of $200 \mathrm{rpm}$ for $24 \mathrm{~h}$. After overnight extraction, the extract was vacuum filtered. The residue from the filtration was air-dried and used in subsequent extraction with dichloromethane, chloroform, ethyl acetate, methanol and sterile water, respectively. The extracts obtained were concentrated in a rotary evaporator (Büchi, Switzerland) at $40^{\circ} \mathrm{C}$ followed by oven-drying to yield hexane (HE), dichloromethane (DcmE), chloroform (ChE), ethyl acetate (EaE) and methanol (ME) extracts. Water extract (WE), was lyophilized until a constant mass was achieved.

By using a separatory funnel, ChE suspended in $100 \mathrm{~mL}$ of distilled water was sequentially partitioned with hexane, diethyl ether and ethyl acetate. This produced the following fractions: hexane $(\mathrm{HF})$, diethyl ether (DeeF), ethyl acetate $(\mathrm{EaF})$ and water (WF). All extracts and fractions were dissolved in 100\% dimethyl sulfoxide (DMSO) except WE and WF were dissolved in distilled water. For bioassays, DMSO percentage of the samples was adjusted to a final concentration of $10 \%(\mathrm{v} / \mathrm{v})$.

\section{Biofilm inhibition assay}

The effect of tempeh extracts and fractions on A. viscosus biofilm formation was measured by the method modified from O'Toole, G. A. (2011). Overnight culture of A. viscosus was diluted in BHI broth to obtain an OD600 of 0.1. The wells of a sterile 96-well flat bottom tissue culture plate, each contained $100 \mu \mathrm{L}$ of final concentrations of extracts/ fraction $(0-3 \mathrm{mg} / \mathrm{ml})$ from stock solution of 100 $\mathrm{mg} / \mathrm{ml}$, with $100 \mu \mathrm{L}$ of an overnight culture of bacteria, were incubated for a biofilm initiation. One hundred microlitres of water and vancomycin $(100 \mu \mathrm{g} / \mathrm{ml})$ in sterile BHI broth were added as negative and positive controls, respectively. For quantitative assays, we typically use triplicate wells for each treatment. Un-inoculated BHI broth was incorporated as a negative control. Following incubation, the crystal violet staining assay was performed to assess biofilm biomass. 


\section{Crystal violet staining assay}

Cell attachment was indirectly assessed using the crystal violet (CV) staining. Following incubation, the plates were washed three times with sterile distilled water to remove unbound cells. The plates were air-dried. Then the generated biofilm was fixed with $10 \%$ formaldehyde, and washed again. Following drying, the wells were stained with $100 \mathrm{ul}$ of $0.1 \%$ crystal violet and incubated at room temperature for $15 \mathrm{~min}$ after which the plates were washed three times with sterile distilled water to remove unabsorbed stain. Following $1 \mathrm{~h}$ of incubation, the $\mathrm{CV}$ was washed twice with distilled water to remove the unbound crystal violet and the stained biofilms were dried at room temperature. Next, $200 \mu \mathrm{L}$ of isopropanol was added to each well to dissolve the dye on the biofilm. The plate was rocked at room temperature for $10 \mathrm{~min}$, and the absorbance was read at $600 \mathrm{~nm}$ using microplate reader (FLUOstar Omega, BMG LabTech).

The results expressed as percentage inhibition (Eqn 1) against the extract concentrations

Percentage inhibition

$=\underline{\mathrm{OD} \text { Negative control }-{ }^{\mathrm{OD}} \text { Experimental }} \times 100$

OD Negative control

The mean absorbance (OD600 $\mathrm{nm}$ ) of the samples was determined, and percentage inhibition obtained (Eqn 1).

\section{Statistical analysis}

All experiments were conducted in triplicates. The differences in mean values among different groups were tested and the values are expressed as mean \pm standard errors (SE). Statistical analysis was carried out using Microsoft Excel. Data obtained analyzed using Student's t-test. The significance of results was set at $\mathrm{p}<0.05(*)$ and $\mathrm{p}<0.01(* *)$.

\section{Scanning electron microscopy (SEM) analysis}

The structure of $A$. viscosus biofilms formed after treatment with $\mathrm{ChE}$ and $\mathrm{HF}$, as well the untreated control, respectively, was observed by SEM modified from Yutao et al., 2016. Briefly, $100 \mu \mathrm{L}$ of overnight-grown A. viscosus suspension diluted in fresh BHI at an initial OD600 of 0.1 and $100 \mu \mathrm{L}$ BHI broth with HF (final concentration $3 \mathrm{mg} / \mathrm{ml}$ ) were added. Glass coverslips (4 $\mathrm{mm}$ in diameter) were prefixed in each well. After incubation for $24 \mathrm{~h}$, the biofilm-coated glass coverslips were immersed in $2.5 \%$ glutaraldehyde at $4{ }^{\circ} \mathrm{C}$ overnight, washed three times with distilled water and dehydrated using ascending graded series of ethanol (30\%, 50\%, 70\%, 80\%, 90\%, and 100\%). The samples were then oven dried. Subsequently, the dried samples were adhered onto double-sided adhesive conductive carbon tape (which was mounted on a copper stage). The samples were then coated with platinum (JEOL JFC-1600 Auto Fine Coater) before viewing by SEM (JSM-6701F, JEOL, Japan). 


\section{Results and Discussion}

\section{Extraction yield of soybean tempeh}

The solvent extraction of bioactive compounds from plants has been widely investigated. Different types of solvents produce different extraction yields. The difference in polarities of the extraction solvents may influence the solubility of the chemical constituents in a sample and thus the extraction yield (Lapormic B et al., 2005; Turkmen $\mathrm{N}$ et al., 2006). The yield of crude extracts as shown in Table 1 was calculated based on the $60 \mathrm{~g}$ of dried and ground tempeh powder initially used for solvent extraction. Yield was calculated using the formula in Eqn 2.

Yield (\%)

$=$ Dry weight of solvent extract $(\mathrm{g}) \quad \mathrm{x} 100 \%$

$\overline{\text { Dry weight of tempeh powder used }}(\mathrm{g})$

Polar solvents extract polar compounds while non-polar solvents extract non-polar compounds ( Handa SS et al., 2008).The yield of HE (18.8 \%) was the highest while EaE gave the lowest (1.78 $\%)$.This suggests that soybean tempeh contained more non-polar than polar compounds. Higher yield achieved by hexane, dichloromethane and chloroform could be explained by their ability to dissolve more non-polar lipophilic compounds (Cosa P et al., 2006). According to De Reu e al., 1994, the concentration of free fatty acids increased in the final product of soybean fermentation (De Reu et al., 1994). Thus, it can be deduced that $27 \%$ out of total recovery yield was non-polar nature due to the higher presence of fatty acids in tempeh sample.

The yield of solvent fractions derived from $\mathrm{ChE}$ was calculated based on $4 \mathrm{~g}$ of crude $\mathrm{ChE}$ ( Table 2). HF was the most abundant extract with $86 \%$ yield which was 7 fold higher than the yield of DeeF. No recovery of samples was found for EaF and WF. This suggests that ChE mostly consisted of non-polar compounds. The repeated hexane extraction step on concentrated $\mathrm{ChE}$ was crucial to acquire a mixture of volatile oils, fats and waxes (Houghton and Raman, 1998). According to Oufnac et al., 2007, in partitioning process alkaloids, aglycones and volatile oils will be forced into the hexane layer while the water layer embodies water-soluble carbohydrate polymers, glycosides and amino acid. Thus, the HF expected to have mixture of volatile oils, and lipid soluble compounds.

\section{Anti-biofilm activity of tempeh extracts and fractions on $A$. viscosus}

Biofilms are notoriously difficult to eradicate because of host defence and inherent resistance to antibiotics and biocides. Furthermore, there are several mechanisms used to explain the resistance of biofilms to antimicrobials (Sillankory S et al., 2003), which makes it difficult to predict the behavior of biofilm cells. In the present study, the initial cell attachment with and without tempeh treatment was evaluated after $24 \mathrm{~h}$ and the percentage of A. viscosus biofilm inhibition was plotted. By comparing the values obtained, it can be seen that tempeh concentrations significantly affected the removal and/or inactivation of biofilm matrix $(\mathrm{p}<0.05)$. To the best of our knowledge, the effect of tempeh extract on the A. viscosus oral biofilm has not yet been documented.

In regards to A. viscosus, only the ChE showed anti-biofilm effect at the four tested concentrations $(0.375,0.75,1.5$ and $3 \mathrm{mg} / \mathrm{ml})$ while the $\mathrm{HE}$ and DcmE showed moderate anti-biofilm activity as illustrated in Figure 1, unlike the EaE, ME and WE which exhibited no such activity even at the 
highest concentration of $3 \mathrm{mg} / \mathrm{ml}$ (Data not shown). Thus, ChE was chosen candidate to be further partitioning. Figure 2 shows that the biofilm of $A$. viscosus was inhibited by HF at the two highest concentrations used $(1.5$ and $3 \mathrm{mg} / \mathrm{ml})$. In this study, we identified that the biofilm of A. viscosus was greatly inhibited by $\mathrm{ChE}$ and $\mathrm{HF}$, and this effect was dosage dependent. The success of $\mathrm{ChE}$ and $\mathrm{HF}$ in inhibiting cell attachment as shown in this study is a promising tool for reducing bacterial colonization and plaque development subsequently leads to periodontal diseases.

It is well known that any kind of agent earmark bacterial viability can be expected to urge selective pressure on the development of antimicrobial resistance. In contrast, repression by natural compounds of bacterial virulence factors that do not affect bacterial growth has advantages such as preserving the host indigenous microflora with less selective pressure on the development of bacterial resistance (Clatworthy A.E et al., 2007; Rasko D.A et al., 2010; Yamasaki S et al., 2011). In the present study, none of the tempeh extracts/ fractions inhibited the growth of A. viscosus. We therefore conclude that the inhibition of adhesion by $\mathrm{ChE}$ and HF cannot have been caused by antibacterial activity on $A$. viscosus, but of an interaction between the extracts and the bacteria, resulting in a loss of adhesion capability.

Incubation of $A$. viscosus with $\mathrm{ChE}$ and $\mathrm{HF}$ reduced adhesion strongly. Washing of the bacteria, which removed non-bound extracts did not restore the adhesion, which suggested a strong interaction between $A$.viscosus and component(s) in the tempeh extracts, which was not lost by washing steps. According to Cerca et al., 2005, it is easier for plant extract to interfere initial cell attachment than inhibiting the growth of preformed biofilm. On the other hand, a notable progress in biofilm exopolymer observed with EaE, ME and WE in this assay may be because of the presence of certain compounds within the extracts that provided a conditioning film promoting microbial adhesion. The enhancement effect observed in this study complements the study reported elsewhere that some natural compounds promote the growth of bacteria (Ofek et al.2003; Sandasi et al. 2008).

\section{SEM analysis on monobiofilm morphology and cellular thickness}

The morphology alteration and cellular thickness of $A$. viscosus biofilm was observed by SEM. As is shown in Figure 3, the biofilm matrix was recorded relatively thick in control while in the ChE and HF treated sample, thickness was reduced up to $67 \%$ and $90 \%$, respectively. As in figure 4, the biofilm integrity and structure in ChE and HF treated sample is gradually being disrupted while homogeneous biofilm was formed in untreated control. Treated A. viscosus biofilm became very sparse and could not cover the surface of the glass slips, and the bacteria cluster became much smaller compared with the control group.

Results of the present study clearly demonstrated that $\mathrm{ChE}$ and HF could inhibit the initiation of $A$. viscosus biofilm exopolymer. The possible explanation could be given is that the active extract may form a coating film on the bacterial surface, or it occupy the specific fimbriae available binding sites, so that they cannot adhere anymore to the tooth pellicle, but instead aggregate into clumps of bacterial cells. Congregate of bacteria were indeed observed via microscopically. This experiment demonstrated that higher concentrations of samples are required to significantly inhibit biofilm cells. This is an expected result since bacteria in the biofilm are strongly protected and less susceptible to antimicrobial agents than in planktonic form.

Therefore, we suppose it can logically reduce oral biofilm incidence rate for susceptible population. If this speculation is correct, tempeh extracts may be used as an integrated drug in oral hygiene care to 
prevent and cure the common oral diseases, including dental caries, gingivitis, periodontal disease, and oral ulcer. To confirm our speculation, more clinical studies of soybean tempeh need to be conducted.

\section{Conclusion}

It is the first study to identify the inhibitory effects of tempeh on A. viscosus oral biofilm formation. The results of this study show potential anti-biofilm activity for tempeh extracts as they are able to inhibit the initial stage of biofilm formation and subsequent growth. The SEM images obtained revealed significant morphological changes and cellular thickness to the bacterial biofilm. However, further studies should be considered, for example, the effects on other cariogenic bacteria, and the clinical study on dosage, efficacy, and cytotoxicity effects of soybean tempeh.

\section{Acknowledgement}

This study was financially supported by Universiti Tunku Abdul Rahman Research Fund (UTARRF).

\section{References}

Ben Slama, R., Kouidhi, B., Zmantar, T., Chaieb, K. and Bakhrouf, A., 2013, Anti-listerial and Antibiofilm Activities of Potential Probiotic Lactobacillus Strains Isolated from Tunisian Traditional Fermented Food. J Food Saf, 33: 8-16.

Cerca, N., Martins, S., Pier, G.B., Oliveira, R. and Azeredo, J., 2005, The relationship between inhibition of bacterial adhesion to a solid surface by sub-MICs of antibiotics and subsequent development of a biofilm. Res Microbiol 156, 650-655.

Clatworthy, A.E., Pierson, E. and Hung, D.T., 2007, Targeting virulence: A new paradigm for antimicrobial therapy. Nat. Chem. Biol. 3:541-548.

Cosa, P., Vlietinck, A.J., Berghe, D.V. and Maes, L., 2006, Anti-infective potential of natural products: How to develop a stronger in vitro 'proof-of-concept'. J Ethnopharmacol, 106:290-302.

Costerton, W., Veeh, R., Shirtliff, M., Pasmore, M., Post, C. and Ehrlich, G., 2003, The application of biofilm science to the study and control of chronic bacterial infections. The Journal of Clinical Investigation. 112(10):1466-1477.

De Reu, J.C., Ramdaras, D., Rombouts, F.M. and Nout, M.J.R., 1994, Changes in soya bean lipids during tempe fermentation. Food Chemistry 50, pp. 171-175.

Fadia Ben Taheur, Bochra Kouidhi, Kais Fdhila, Hamouda Elabed, Rihab Ben Slama, Kacem Mahdouani, Amina Bakhrouf, and Kamel Chaieb, 2016, Anti-bacterial and anti-biofilm activity of probiotic bacteria against oral pathogens. In Microbial Pathogenesis, Volume 97, pp. 213-220.

Gibbons, R. J., 1989, Bacterial adhesion to oral tissues: a model for infectious diseases. J Dent Res, 68: 750-760.

Handa, S.S., Khanuja, S.P.S., Longo, G. and Rakesh, D.D., 2008, Extraction Technologies for Medicinal and Aromatic Plants. International centre for science and high technology, Trieste, pp.2125.

Haron, H., Shahar, S., O'Brien, K. O., Ismail, A., Kamaruddin, N. and Rahman, S. A., 2010, Absorption of calcium from milk and tempeh consumed by postmenopausal Malay women using the dual stable isotope technique. International Journal of Food Science and Nutrition 61, 125-137.

Haron, H., Ismail, A., Shahar, S., Azlan, A. and Peng, L. S., 2011, Apparent bioavailability of isoflavones in urinary excretions of postmenopausal Malay women consuming tempeh compared with milk. International Journal of Food Science and Nutrition 62(6), 642-650.

Houghton, P.J. and Raman, A., 1998, Laboratory Handbook for Fractionation of Natural Extracts. Chapman and Hall, London, 199 p.

Karmini, M., Affandi, E., Hermana, Karyadi, D. and Winarno, F., 1997, The inhibitory effect of tempe on Escherichia coli infection. In: International Tempe Symposium. Bali, Indonesia: Indonesian Tempe Foundation. 
Karyadi, D., Mahmud, M.K. and Hermana, 1990, Locally made rehabilitation foods. In The Malnourished Child ed. Suskind, R.M. and Lewinter-Suskind, L. pp. 371-381. New York, NY: Raven Press.

Keuth, S. and Bisping, B.,1993, Formation of vitamins by pure culture of tempeh molds and bacteria during the tempeh solid substrate fermentation. Journal of Applied Bacteriology 75, 427-434.

Khan, I. and Kang, S. C., 2016, Probiotic potential of nutritionally improved Lactobacillus plantarum DGK-17 isolated from Kimchi-A traditional Korean fermented food. Food Control 60 88-94.

Kiers, J.L., Nout, M.J.R., Rombouts, F.M., Nabuurs, M.J.A. and Van der Meulen, J., 2002, Inhibition of adhesion of enterotoxic Escherichia coli K88 by soya bean tempe. Lett Appl Microbiol 35, 311315 .

Kostakioti, M., Hadjifrangiskou, M. and Hultgren, S.J., 2013, Bacterial biofilms: development, dispersal, and therapeutic strategies in the dawn of the postantibiotic era. Cold Harb Perspect Med, 3:a010306.

Kuligowski, M., Jasińska-Kuligowska, I. and Nowak, J., 2013, Evaluation of bean and soy tempeh influence on intestinal bacteria and estimation of antibacterial properties of bean tempeh. Polish Journal of Microbiology, 62, 189-194.

Lapornik, B., Prosek, M. and Wondra, A., 2005, Comparison of extracts prepared from plant byproducts using different solvents and extraction time. J Food Eng.71:214-222.

Maria Daglia, Monica Stauder, Adele Papetti, Caterina Signoretto, Giovanni Giusto, Pietro Canepari, Carla Pruzzo and Gabriella Gazzani, 2010, Isolation of red wine components with anti-adhesion and anti-biofilm activity against Streptococcus mutans. In Food Chemistry, Volume 119, Issue 3, pp. 1182-1188.

Marsh, P. and Martin, M., 1992, Oral microbiology. 3rd ed. London: Chapman \& Hall.

Murakami, H., Asakawa, T., Terao, J. and Matsushita, S., 1984, Anti-oxidative stability of tempeh and liberation of isoflavones by fermentation. Agriculture and Biological Chemistry 48(12), 29712975.

Murata, K., Ikehata, H., and Miyamoto, T., 1967, Studies on the Nutritional Value of Tempeh. Journal of Food Science, 32: 580-586.

Mo, H., Zhu, Y. and Nout, M.J., 2011, In vitro digestion enhances anti-adhesion effect of tempeh and tofu against Escherichia coli. Lett. Appl. Microbiol, 54:166-168.

Nagy, B. and Fekete, P.Z., 2005, Enterotoxigenic Escherichia coli in veterinary medicine. Int. J. Med. Microbiol. 295:443-454.

Nataro, J.P., and Kaper, J.B., 1998, Diarrheagenic Escherichia coli. Clin. Microbiol. Rev. 11:142-201. Nyvad, B. and Kilian.,1987, M. Microbiology of the early colonization of human enamel and root surfaces in vivo. Scand J Dent Res, 95: 369-380.

Ofek, I., Hasty, D.L. and Sharon, N., 2003, Anti-adhesion therapy of bacterial diseases: prospects and problems. FEMS Immunol Med Microbiol 38, 181-191.

O’Toole, G. A., 2011, Microtiter Dish Biofilm Formation Assay. Journal of Visualized Experiments : JoVE, (47), 2437. Advance online publication.

Oufnac, D.S., Xu, Z., Sun, T., Sabliov, C., Prinyawiwatkul, W. and Godber, J.S., 2007, Extraction of antioxidants from wheat bran using conventional solvent and microwave assisted methods. Cereal Chem. 84:125-129.

Rasko, D.A. and Sperandio, V., 2010, Anti-virulence strategies to combat bacteria-mediated disease. Nat. Rev. Drug Discov.9:117-128. doi: 10.1038/nrd3013.

Rao, K.P., Chennappa, G., Suraj, U., Nagaraja H, Charith Raj A.P., Sreenivasa, M.Y., 2015, Probiotic Potential of Lactobacillus Strains isolated from sorghum-based traditional fermented food. Probiotics \& Antimicro Prot., 7:146-156

Roubos van den Hil, P., Dalmas, E., Nout, R. and Abee, T., 2008, Inactivation of Bacillus cereus cells and spores by low molecular weight proteinaceous compounds extracted from soybean tempeh. Abstracts of the 21st International ICFMH Symposium "Evolving microbial food quality and safety. FoodMicro 2008. Aberdeen. Scotland. p.107.

Roubos-van den Hil, P.J., Nout, M.J.R., Beumer, R.R., Van der Meulen J. and Zwietering, M.H., 2009, Fermented soya bean (tempe) extracts reduce adhesion of enterotoxigenic Escherichia coli to intestinal epithelial cells. J Appl Microbiol 106, 1013-1021. 
Sandasi, M., Leonard, C.M. and Viljoen, A.M., 2008, The effect of five common essential oil components on Listeria monocytogenes biofilms. Food Control 19, 1070-1075.

Sillankorv, S., Oliveira, R., Vieira, M.J., Sutherland, I. and Azeredo, J., 2004, Bacteriophage S1 infection of Pseudomonas fluorescent planktonic cells versus biofilms. J Biofouling, 20:133-138.

Slobodníková, Lívia., Fialová, Silvia., Rendeková, Katarína., Kováč, Ján. and Mučaji, Pavel., 2016, Antibiofilm Activity of Plant Polyphenols. Molecules 21, no. 12: 1717.

Socransky, S. S., Manganiello, A. D., Propas, D., Oram, V. and Van Houte, J., 1977, Bacteriological studies of developing supragingival dental plaque. J Periodontal Res.12: 90-106

Steinberg, D., 2000, Studying plaque biofilms on various dental surfaces. Handbook of Bacterial Adhesion: Principles, Methods, and Application. pp. 353-370. Humana Press, Totowa, NJ.

Stewart, P. S. and Costerton, J. W., 2001, Antibiotic resistance of bacteria in biofilms. Lancet 358, 135-138.

Sutardi. and Buckle, K. A., 1985, Reduction in phytic acid levels in soybeans during tempeh production, storage, and frying. Journal of Food Science 50(1), 260-263.

Takahashi, N. and Nyvad, B., 2011, The role of bacteria in the caries process: ecological perspectives. Journal of Dental Research, 90(3):294-303.

Theilade, E., Fejerskov, O., Karring, T., and Theilade, J., 1982, Predominant cultivable microflora of human dental fissure plaque. Infect Immune, 36: 977-982.

Trentin, D.S., Giordani, R.B., Macedo, A.J., 2013, Biofilmes bacterianos patogênicos: aspectos gerais, importância clínica e estratégias de combate Rev. Liberato, 14, pp. 113-23.

Tsangalis, D., Ashton, J. F., Mcgill, A. E. J., and Shah, N. P., 2002, Enzymatic transformation of isoflavones phytoestrogens in soymilk by $\beta$-glucosidase-producing Bifidobacteria. Journal of Food Science 67(8), 3104-3114.Vaz-Moreir

Turkmen, N., Sari, F. and Velioglu, Y., 2006, Effect of extraction solvents on concentration and antioxidant activity of black and black mate polyphenols determined by ferrous tartrate and FolinCiocalteu methods. Food Chem.pp.99:838-841.

Wadhwani, T., Desai, K., Patel, D., Lawani, D., Bahaley, P., Joshi, P. and Kothari, V., 2008, Effect of various solvents on bacterial growth in context of determining MIC of various antimicrobials. The Internet Journal of Microbiology, Volume 7 No 1.

Yamasaki, S., Asakura, M., Neogi, S.B., Hinenoya A., Iwaoka E. and Aoki S., 2011, Inhibition of virulence potential of Vibrio cholerae by natural compounds. Indian J. Med. Res.133:232-239.

Yutao Yang, Shiyu Liu, Yuanli He, Zhu Chen, and Mingyun Li, 2016, Effect of LongZhang Gargle on Biofilm Formation and Acidogenicity of Streptococcus mutans In Vitro," BioMed Research International, Article ID 5829823, 8 pages. 


\section{Appendix}

Table 1. The weight and percentage yield of crude extracts from tempeh.

\begin{tabular}{lll}
\hline Crude extract & Weight $(\mathrm{g})$ & Yield (\%) \\
\hline $\mathrm{HE}$ & 11.25 & 18.8 \\
\hline $\mathrm{DcmE}$ & 3.05 & 5.08 \\
\hline $\mathrm{ChE}$ & 2.15 & 3.58 \\
\hline $\mathrm{EaE}$ & 1.07 & 1.78 \\
\hline $\mathrm{ME}$ & 3.35 & 5.58 \\
\hline $\mathrm{WE}$ & 2.40 & 4.00 \\
\hline
\end{tabular}

Table 2. The weight and percentage yield of fractions partitioned from $\mathrm{ChE}$.

\begin{tabular}{lll}
\hline Fraction & Weight $(\mathrm{g})$ & Yield (\%) \\
\hline $\mathrm{HF}$ & 3.44 & 86.0 \\
\hline $\mathrm{DeeF}$ & 0.50 & 12.5 \\
\hline $\mathrm{EaF}$ & 0.0 & - \\
\hline $\mathrm{WF}$ & 0.0 & - \\
\hline
\end{tabular}




\section{International Conference on Drug Discovery \& Development (ICDDD 2017)}

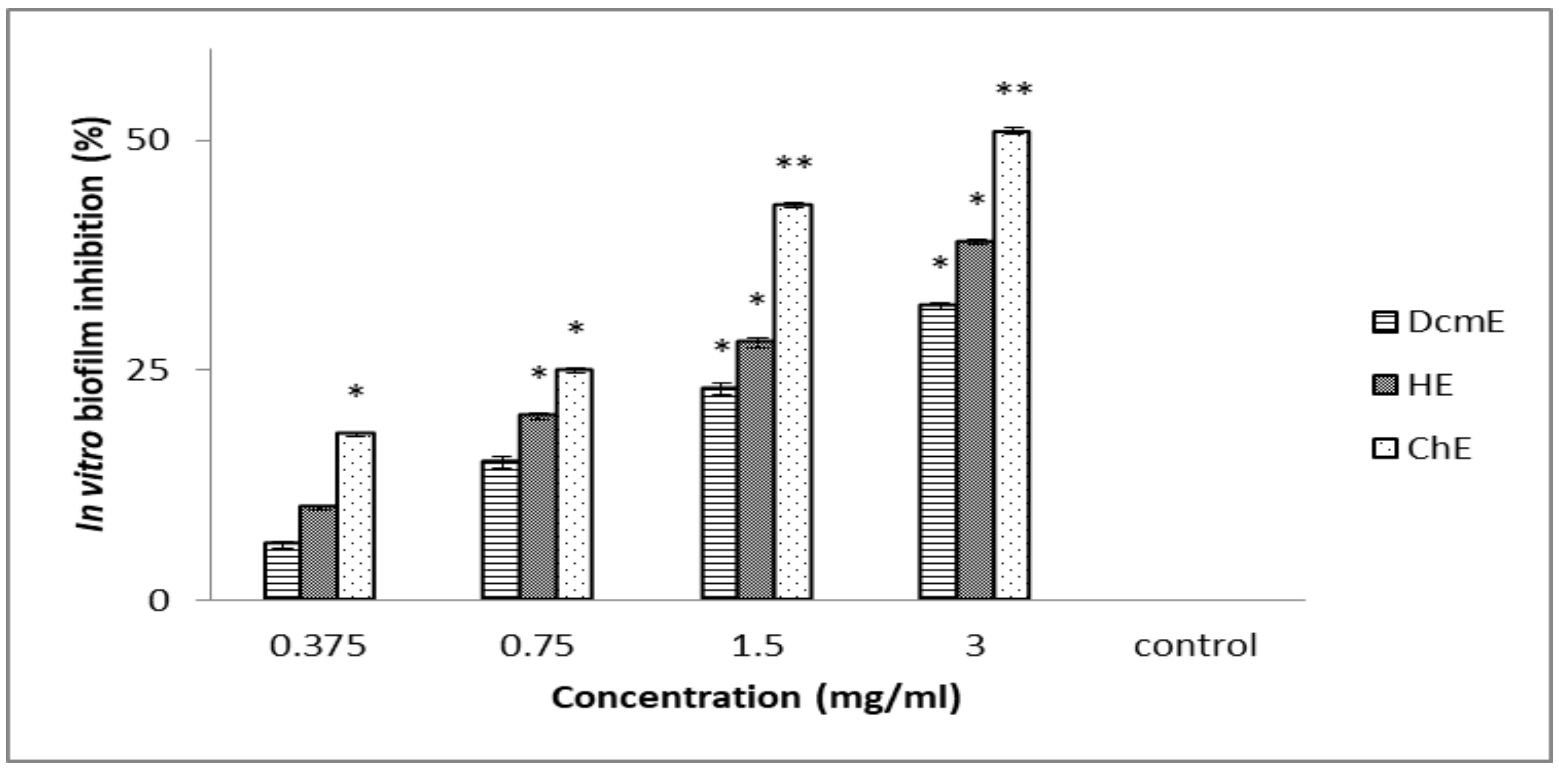

Figure 1: Percent inhibition of biofilm formation exhibited by dichloromethane (DcmE), hexane (HE) and chloroform (ChE) extracts of tempeh against A. viscosus biofilm. Average data $(\mathrm{n}=3)$ are presented with SE. A value of $\mathrm{p}<0.05(*)$ or $\mathrm{p}<0.01(* *)$ was performed by Student's t-test and compared to control group without treatment.

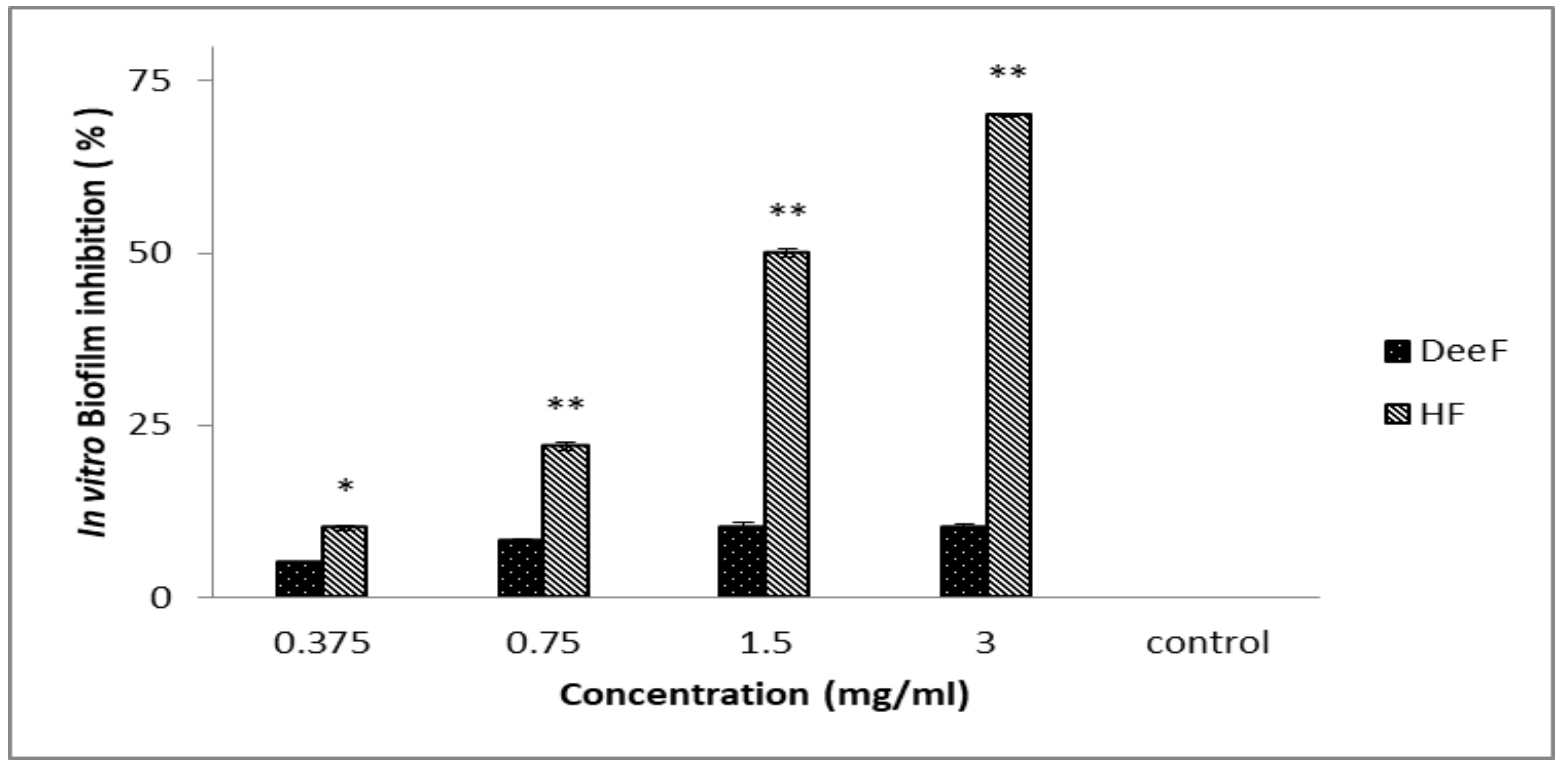

Figure 2: Percent inhibition of biofilm formation exhibited by diethyl ether (DeE) and hexane (HF) fractions against A. viscosus biofilm. Average data $(\mathrm{n}=3)$ are presented with SE. A value of $\mathrm{p}<0.05\left(^{*}\right)$ or $\mathrm{p}<0.01(* *)$ was performed by Student's t-test and compared to control group without treatment. 


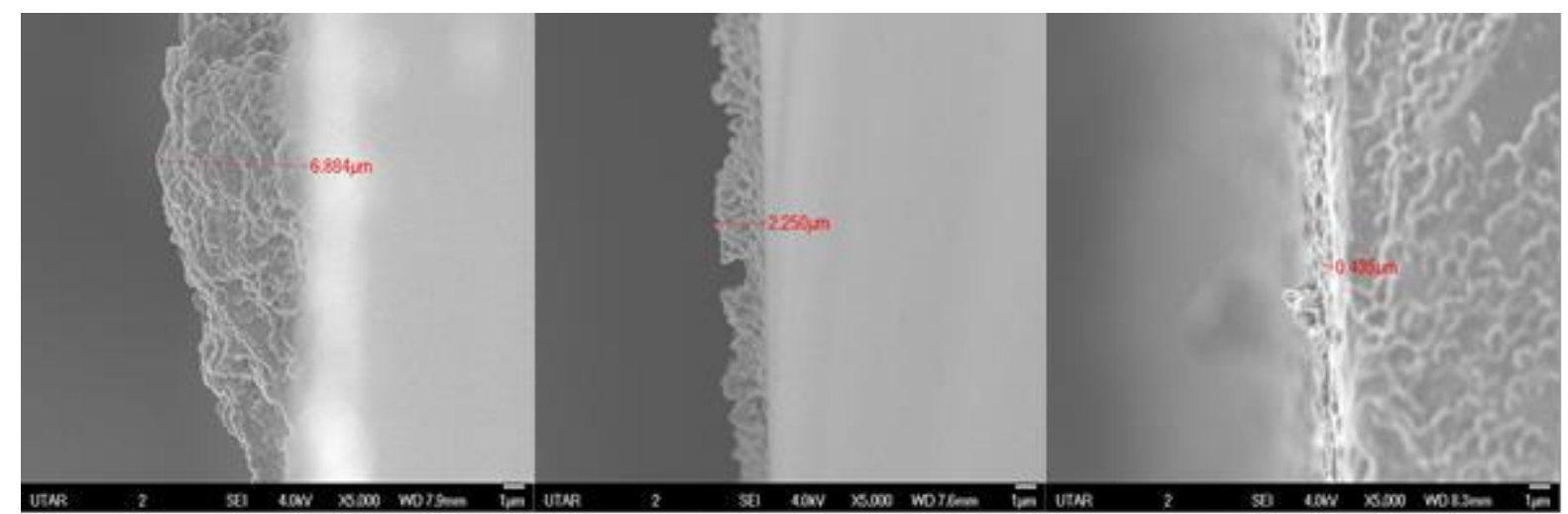

Figure 3: Effect of $\mathrm{ChE}$ and $\mathrm{HF}$ on monobiofilm thickness profile $(\mu \mathrm{m})$. A viscosus was incubated for $24 \mathrm{~h}$ in BHI broth, with $\mathrm{ChE}(\mathrm{B})$ and $\mathrm{HF}(\mathrm{C})$ in a concentration of $3 \mathrm{mg} / \mathrm{ml}$. The untreated control (A) group was also conducted via vertical view SEM imaging, under magnification X5000.

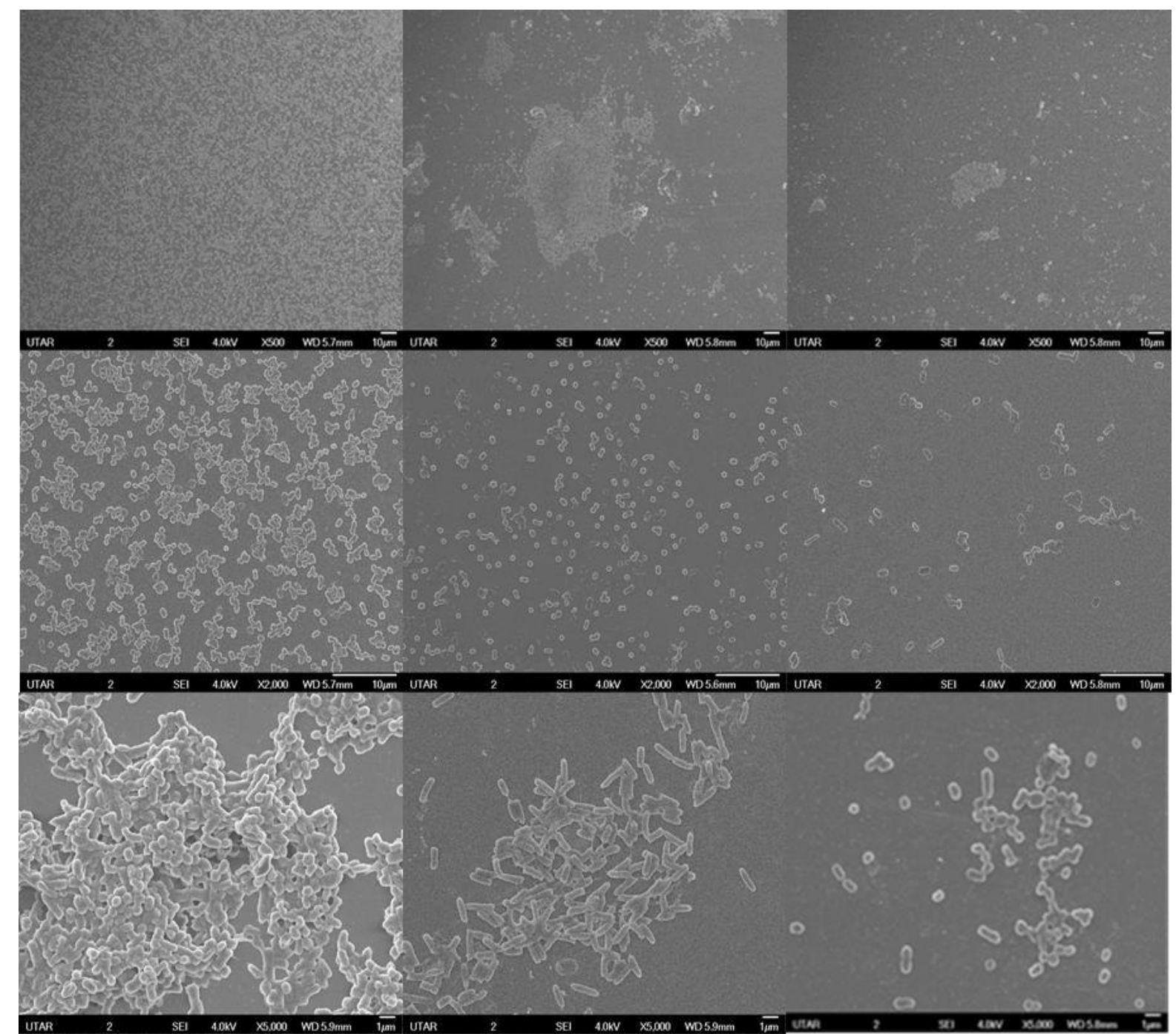

Figure 4: Effect of HF on biofilm morphology. A viscosus was incubated for $24 \mathrm{~h}$ in BHI broth, with $\mathrm{ChE}$ (B) and HF (C) in $3 \mathrm{mg} / \mathrm{ml}$. The untreated control (A) was also conducted under X500, X2000 and X5000. 